\title{
Bioguided Isolation of Alkaloids and Pharmacological Effects of the Total Alkaloid Fraction from Aspidosperma pyrifolium Mart. (Apocynaceae)
}

\author{
Francisca Sabrina Vieira Lins ${ }^{1}$, Vanessa Farias da Silva ${ }^{2}$, Josean Fechine Tavares ${ }^{3} \mathbb{D}$, Vanda Lúcia dos Santos ${ }^{1}$ \\ and Harley da Silva Alves ${ }^{1, *}$ \\ 1 Department of Pharmacy, Post-Graduate Program in Pharmaceutical Sciences, \\ State University of Paraíba, Campina Grande 58429-500, PB, Brazil; \\ sabrinav.lins@gmail.com (F.S.V.L.); vandalsantos@servidor.uepb.edu.br (V.L.d.S.) \\ 2 National Semiarid Institute, Campina Grande 58429-500, PB, Brazil; belaatiria@hotmail.com \\ 3 Institute for Research in Pharmaceuticals and Medications, Federal University of Paraíba, \\ João Pessoa 58051-900, PB, Brazil; josean@ltf.ufpb.br \\ * Correspondence: harley@servidor.uepb.edu.br; Tel.: +55-83-33153300
}

check for

updates

Citation: Lins, F.S.V.; da Silva, V.F.; Tavares, J.F.; dos Santos, V.L.; da Silva Alves, H. Bioguided Isolation of Alkaloids and Pharmacological Effects of the Total Alkaloid Fraction from Aspidosperma pyrifolium Mart. (Apocynaceae). Plants 2021, 10, 2526. https://doi.org/10.3390/plants10112526

Academic Editor: Salvatore

Antonino Raccuia

Received: 2 November 2021

Accepted: 17 November 2021

Published: 20 November 2021

Publisher's Note: MDPI stays neutral with regard to jurisdictional claims in published maps and institutional affiliations.

Copyright: (c) 2021 by the authors. Licensee MDPI, Basel, Switzerland. This article is an open access article distributed under the terms and conditions of the Creative Commons Attribution (CC BY) license (https:// creativecommons.org/licenses/by/ $4.0 /)$.

\begin{abstract}
Aspidosperma pyrifolium is used in traditional medicine to treat inflammatory disorders. The aim of the study was to perform phytochemical characterization and evaluate the anti-inflammatory, anti-nociceptive and acute toxicity effects of the total alkaloid fraction (TAF-Ap) from stem barks. Two monoterpenic indole alkaloids were isolated by high performance liquid chromatography coupled with mass spectrometry (HPLC-MS) and the structural elucidation was performed using 1D and 2D NMR analysis. As for toxicity, no animals died at $50 \mathrm{mg} \mathrm{kg}^{-1}$ and this concentration presented mild sedation and forced breathing within the first $24 \mathrm{~h}$. The lethal dose capable of killing $50 \%$ of the animals ( $\mathrm{LD}_{50}$ ) was estimated to be $160 \mathrm{mg} \mathrm{kg}^{-1}$. In the pharmacological tests, the models used were $1 \%$ carrageenan-induced paw edema and peritonitis, $1 \%$ formalin-induced nociception and 1\% acetic acid-induced abdominal writhing in Swiss mice. The study made it possible to isolate 15-methoxyaspidospermine and 15-methoxypyrifolidine, corroborating the results of pharmacological assays, which showed anti-inflammatory and analgesic potential, especially at $30 \mathrm{mg} \mathrm{kg}^{-1}(p<0.001)$. Thus, the species was shown to be a promising source of active substances, with special attention paid to its toxicological potential.
\end{abstract}

Keywords: pereiro-preto; plumeran alkaloids; acute toxicity; anti-inflammatory; anti-nociceptive

\section{Introduction}

Inflammation is an immune defense mechanism that the body uses to fight bacteria, viruses and other pathogens [1,2]. In these processes, a variety of chemical mediators are released from damaged tissue, including excitatory amino acids, hydrogen ions, peptides, lipids, and cytokines, all of which underlie inflammation and pain [3].

Non-steroidal anti-inflammatory drugs, such as aspirin, as well as steroidal antiinflammatory drugs, such as dexamethasone, have been widely used to fight inflammation, but there is clinical evidence that these drugs are capable of causing adverse effects, including gastrointestinal disorders. Alternatively, natural products are growing targets in research for new drug discovery [1,4].

Aspidosperma pyrifolium Mart., popularly known as "pereiro-preto", is a small tree that is widely distributed in northeastern Brazil, more precisely in the Caatinga. Its wood is used in the manufacture of furniture, due to its excellent quality [5-7]; in traditional medicine, the extract of its leaves and bark is used for its anti-inflammatory and analgesic properties [7-9]. 
Previous studies have shown a hypotensive effect attributed to the alkaloids present in the bark and leaves of this species, as well as anti-plasmodic activity related to the presence of aspidosperman alkaloids, such as the alkaloid aspidospermin [9,10].

Although there are pharmacological and phytochemical studies of crude extracts from $A$. pyrifolium, there is no information on the therapeutic potential of the isolated fraction of alkaloids present in the species. Therefore, the present study aimed to test the anti-inflammatory and anti-nociceptive potential of the fraction of alkaloids extracted from A. pyrifolium husks and to isolate the indolic alkaloids present in this fraction, showing that the therapeutic potential produced is related to these substances.

\section{Results and Discussion}

\subsection{Chemical Identification of Isolated Compounds}

The qualitative analysis by HPLC-DAD of TAF-Ap indicated the presence of two alkaloids. The acquisition of the 3D chromatogram with scanning from 200 to $400 \mathrm{~nm}$ (Figure 1) pointed the presence of the alkaloids with absorption greater than $200 \mathrm{mAU}$ and retention times of 7.68 and $7.78 \mathrm{~min}$, respectively.

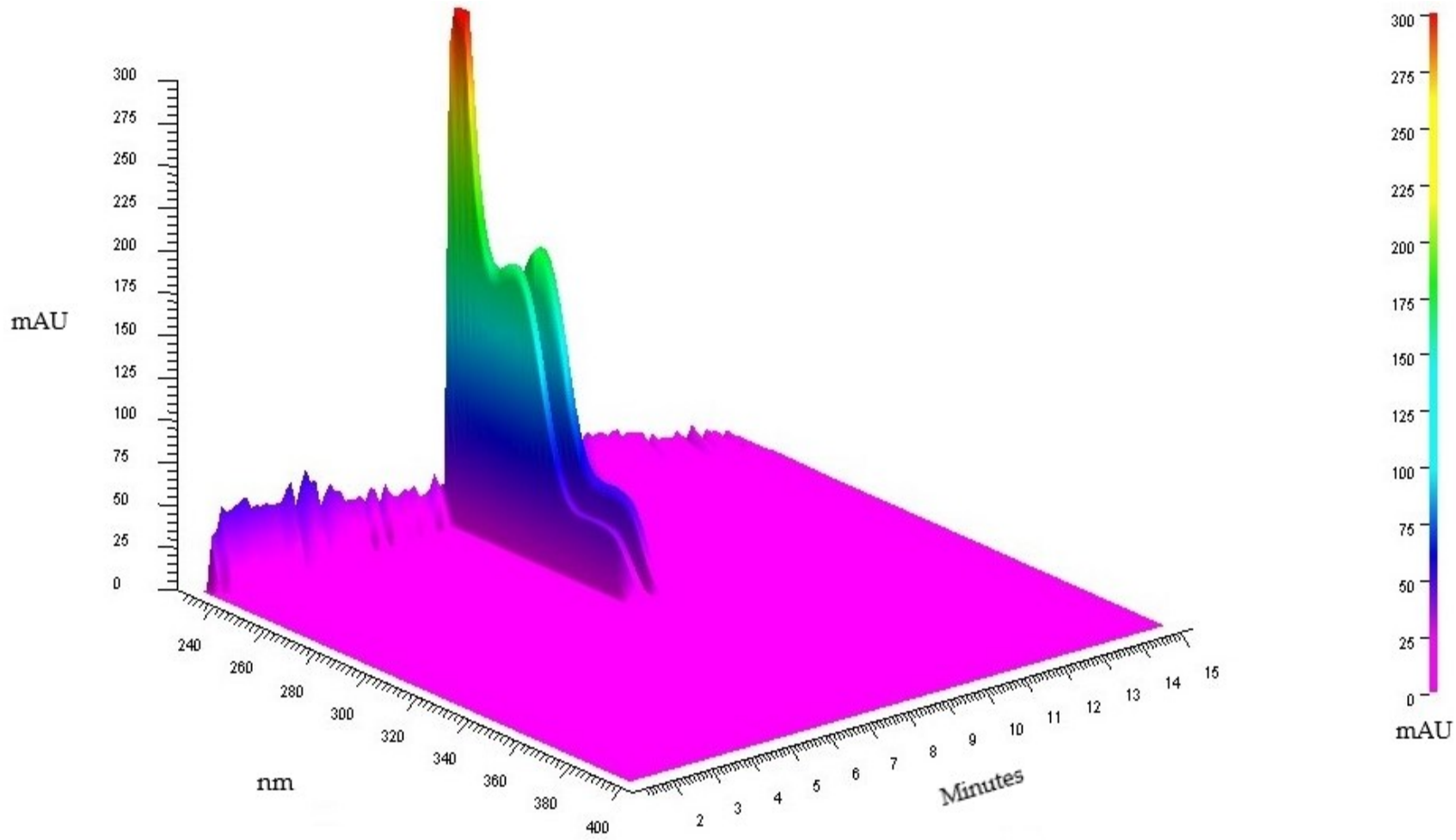

Figure 1. 3D chromatogram of an exploratory analysis of TAF-Ap.

The mass spectra of 1 and 2 showed molecular ion peaks at $m / z=385.44$ (calcd $m / z$ 384.241) and $m / z=415.45$ (calcd $m / z$ 414.252), which allowed us to manage the following structural formulas: $\mathrm{C}_{23} \mathrm{H}_{32} \mathrm{~N}_{2} \mathrm{O}_{3}$ and $\mathrm{C}_{24} \mathrm{H}_{34} \mathrm{~N}_{2} \mathrm{O}_{4}$, respectively. The UV spectrum showed three absorption bands at $\lambda_{\max }$.222, 256 and $285 \mathrm{~nm}$ (Figure S1), suggestive of indoline chromophore [11].

The ${ }^{1} \mathrm{H}$ NMR data $\left(500 \mathrm{MHz}\right.$, acetone- $\left.\mathrm{d}_{6}\right)$ (Table 1) (Figures S2-S5) showed four signals aromatic hydrogen at $\delta_{\mathrm{H}} 7.16(\mathrm{t}, J=7.8,1 \mathrm{H}), \delta_{\mathrm{H}} 7.06(\mathrm{~d}, J=8.2 \mathrm{~Hz}, 1 \mathrm{H}), \delta_{\mathrm{H}} 7.00(\mathrm{~d}$, $J=8.2 \mathrm{~Hz}, 1 \mathrm{H})$ and $\delta_{\mathrm{H}} 6.82(\mathrm{dd}, J=8.3$ and $1.9 \mathrm{~Hz}, 2 \mathrm{H})$. In addition to these signals, others were visualized between $\delta_{\mathrm{H}} 3.86$ and 0.68 , suggestive of aliphatic hydrogens $[9,11]$. 
Table 1. ${ }^{1} \mathrm{H}$ and ${ }^{13} \mathrm{C}$ NMR data of 15 -methoxyaspidospermine (1) and 15-methoxypyrifolidine (2) $\left(\delta\right.$, acetone- $\mathrm{d}_{6}, 500$ and $125 \mathrm{MHz})$.

\begin{tabular}{|c|c|c|c|c|}
\hline Position & & 1 & & 2 \\
\hline $\mathrm{C}$ & $\delta_{C}$ & $\delta_{H}$ & $\delta_{C}$ & $\delta_{H}$ \\
\hline 2 & 67.67 & $4.93(\mathrm{dd}, J=6.2$ and $10.7 \mathrm{~Hz}, 1 \mathrm{H})$ & 67.90 & $4.85(\mathrm{dd}, J=6.1$ and $10.6 \mathrm{~Hz}, 1 \mathrm{H})$ \\
\hline 3 & 52.83 & $3.26(\mathrm{brd}, J=8.2 \mathrm{~Hz}, 1 \mathrm{H})$ and $2.17(\mathrm{~m}, 1 \mathrm{H})$ & 52.70 & $3.26(\mathrm{brd}, J=8.2 \mathrm{~Hz}, 1 \mathrm{H})$ and $2.17(\mathrm{~m}, 1 \mathrm{H})$ \\
\hline 5 & 52.80 & $3.37(\mathrm{~d}, J=6.8 \mathrm{~Hz}, 1 \mathrm{H})$ and $2.36(\mathrm{~m}, 1 \mathrm{H})$ & 52.70 & $3.37(\mathrm{~d}, J=6.8 \mathrm{~Hz}, 1 \mathrm{H})$ and $2.36(\mathrm{~m}, 1 \mathrm{H})$ \\
\hline 6 & 37.71 & $\begin{array}{c}2.06(\mathrm{brt}, J=2.2 \mathrm{~Hz}, 1 \mathrm{H}) \text { and } \\
1.92(\mathrm{dd}, J=3.8 \text { and } 15.2 \mathrm{~Hz}, 1 \mathrm{H})\end{array}$ & 37.35 & $\begin{array}{c}(\mathrm{brt}, J=2.2 \mathrm{~Hz}, 1 \mathrm{H}) \text { and } 1.92(\mathrm{dd}, J=3.8 \text { and } \\
15.2 \mathrm{~Hz}, 1 \mathrm{H})\end{array}$ \\
\hline 7 & 52.80 & - & 52.83 & - \\
\hline 8 & 141.65 & - & 141.65 & - \\
\hline 9 & 110.38 & $6.82(\mathrm{dd}, J=8.3$ and $1.9 \mathrm{~Hz}, 2 \mathrm{H})$ & 117.39 & $7.06(\mathrm{~d}, J=8.2 \mathrm{~Hz}, 1 \mathrm{H})$ \\
\hline 10 & 127.42 & $7.16(\mathrm{t}, J=7.8,1 \mathrm{H})$ & 113.45 & $7.00(\mathrm{~d}, J=8.2 \mathrm{~Hz}, 1 \mathrm{H})$ \\
\hline 11 & 110.09 & $6.82(\mathrm{dd}, J=8.3$ and $1.9 \mathrm{~Hz}, 2 \mathrm{H})$ & 154.66 & - \\
\hline 12 & 141.68 & - & 150.10 & - \\
\hline 13 & 133.50 & - & 134.33 & - \\
\hline 14 & 24.44 & $2.03(\mathrm{~m}, 1 \mathrm{H})$ and $1.59(\mathrm{brd}, J=3.8 \mathrm{~Hz}, 1 \mathrm{H})$ & 24.33 & $2.03(\mathrm{~m}, 1 \mathrm{H})$ and $1.59(\mathrm{brd}, J=4.5 \mathrm{~Hz}, 1 \mathrm{H})$ \\
\hline 15 & 74.02 & $3.26(\mathrm{brd}, J=9.0 \mathrm{~Hz}, 1 \mathrm{H})$ & 74.50 & $3.17(\mathrm{brd}, J=14.3 \mathrm{~Hz}, 1 \mathrm{H})$ \\
\hline 16 & 24.77 & $2.00(\mathrm{~m}, 1 \mathrm{H})$ and $1.35(\mathrm{~m}, 1 \mathrm{H})$ & 24.60 & $2.00(\mathrm{~m}, 1 \mathrm{H})$ and $1.35(\mathrm{~m}, 1 \mathrm{H})$ \\
\hline 17 & 24.33 & $2.03(\mathrm{~m}, 1 \mathrm{H})$ and $1.37(\mathrm{~m}, 1 \mathrm{H})$ & 24.44 & $2.03(\mathrm{~m}, 1 \mathrm{H})$ and $1.37(\mathrm{~m}, 1 \mathrm{H})$ \\
\hline 18 & 6.77 & $0.69(\mathrm{t}, J=7.5 \mathrm{~Hz}, 3 \mathrm{H})$ & 6.84 & $0.68(\mathrm{t}, J=7.5 \mathrm{~Hz}, 3 \mathrm{H})$ \\
\hline 19 & 30.45 & $1.05(\mathrm{q}, J=7.3 \mathrm{~Hz}, 2 \mathrm{H})$ & 29.98 & $1.00(\mathrm{q}, J=7.3 \mathrm{~Hz}, 2 \mathrm{H})$ \\
\hline 20 & 36.59 & 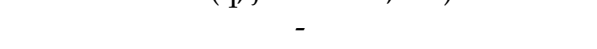 & 36.57 & - \\
\hline 21 & 71.17 & $3.80(\mathrm{~s}, 1 \mathrm{H})$ & 71.15 & $3.81(\mathrm{~s}, 1 \mathrm{H})$ \\
\hline $11-\mathrm{OCH}_{3}$ & - & - & 56.53 & $3.83(\mathrm{~s}, 3 \mathrm{H})$ \\
\hline $12-\mathrm{OCH}_{3}$ & 56.01 & $3.84(\mathrm{~s}, 3 \mathrm{H})$ & 56.53 & $3.86(\mathrm{~s}, 3 \mathrm{H})$ \\
\hline $15-\mathrm{OCH}_{3}$ & 56.74 & $3.31(\mathrm{~s}, 3 \mathrm{H})$ & 56.74 & $3.31(\mathrm{~s}, 3 \mathrm{H})$ \\
\hline $\mathrm{NCOCH}_{3}$ & 169.59 & & 170.26 & \\
\hline $\mathrm{NCOCH}_{3}$ & 22.93 & $2.18(\mathrm{~s}, 3 \mathrm{H})$ & 22.98 & $2.19(\mathrm{~s}, 3 \mathrm{H})$ \\
\hline
\end{tabular}

The ${ }^{13} \mathrm{C}-\mathrm{NMR}$ spectrum $\left(125 \mathrm{MHz}\right.$, acetone- $\mathrm{d}_{6}$ ) (Table 1) (Figures S6 and S7) showed 31 signals: 9 from unhydrogenated carbons, 7 from $\mathrm{CH}$ carbons, 7 from $\mathrm{CH}_{2}$ carbons and 8 from $\mathrm{CH}_{3}$ carbons. The signals at $\delta_{\mathrm{C}} 110.38,110.09,127.42,117.39$ and 113.45 are characteristic of aromatic methinic carbons. In addition, the signals at $\delta_{C} 141.65$, $141.68,133.50,154.66,150.10$ and134.33 are consistent with non-hydrogenated aromatic carbons [9,12].

The heteronuclear correlation map-HSQC (Figures S8 and S9) showed the following correlations: $\delta_{\mathrm{H}} 6.82 / \delta_{\mathrm{C}} 110.38$ and 110.09 (C-9 and C-11) and $\delta_{\mathrm{H}} 7.16 / \delta_{\mathrm{C}} 127.42(\mathrm{C}-10)$, suggestive of a tri-substituted aromatic nucleus. The correlations of $\delta_{\mathrm{H}} 7.06 / \delta_{\mathrm{C}} 117.39$ (C-9) and $\delta_{\mathrm{H}} 7.00 / \delta_{\mathrm{C}} 113.45(\mathrm{C}-10)$ are suggestive of another tetra-substituted aromatic ring [9]. The correlations between $\delta_{\mathrm{H}} 3.84 / \delta_{\mathrm{C}} 141.68$ e $\delta_{\mathrm{H}} 3.83 / \delta_{\mathrm{C}} 154.66$ e $\delta_{\mathrm{H}} 3.86 / \delta_{\mathrm{C}} 150.10$, seen in the heteronuclear correlation map-HMBC (Figures S10-S12), confirm the presence of methoxyl groups in C-11, C-11 and C-12 in the two aromatic nuclei, respectively. According to [9], the signals at $\delta_{C} 169.59$ and $\delta_{C} 170.26$ suggested the presence of $N$-acethyl carbonyl groups, in addition to a signal at $\delta_{C} 52.80$ and 52.83, characteristic of C-7 indolic-ring quaternary carbon. These positions were confirmed by long-range heteronuclear correlation at $\delta_{\mathrm{H}} 2.18 / \delta_{\mathrm{C}} 169.59 ; \delta_{\mathrm{H}} 2.19 / \delta_{\mathrm{C}} 170.26$ and $\delta_{\mathrm{H}} 6.82 / \delta_{\mathrm{C}} 52.80$; and $\delta_{\mathrm{H}} 7.06 / \delta_{\mathrm{C}} 52.83$.

All the methylene carbons were displayed by ${ }^{13} \mathrm{C}$ NMR and experiment APT and the hydrogens attached to them were revealed by chemical shifts, coupling constants and comparison with data from previous research. The signals at $\delta_{C} 71.17$ and 71.15 were attributed to the methinic carbons of the position 21, respectively.

A signal at $\delta_{\mathrm{H}} 3.31(\mathrm{~s}, 6 \mathrm{H})$ showed a correlation in the HSQC with $\delta_{\mathrm{C}} 56.74$ and suggested the presence of other methoxyl groups in the compounds. Methoxyl insertion at C-15 was reinforced by $\alpha$ deprotection in this carbon, $\beta$ deprotection at C-14 and C-20 and $\gamma$ protection at $\mathrm{C}-19$ and $\mathrm{C}-3$, when compared to a structure without this substituent and confirmed by correlations of $\delta_{\mathrm{H}} 3.31 / \delta_{\mathrm{C}} 74.02$ and 74.50 , seen in the HMBC. In addition, the 
coupling constants for the two broad doublets at $\delta_{\mathrm{H}} 3.26(J=9.0 \mathrm{~Hz})$ and $3.17(J=14.3 \mathrm{~Hz})$ were in accordance with the expected values when the hydrogens $\mathrm{H}-15$ were located in the $\alpha$ position in relation to ring $D$. Therefore, it can be deduced that $\mathrm{OCH}_{3}-15$ features pseudo-equatorial stereochemistry [13]. The correlation between $\delta_{\mathrm{H}} 2.03 / \delta_{\mathrm{H}} 3.17$ and 3.26 , observed in the NOESY spectrum (Figure S13), reinforce this argument.

The interpretation of spectral data, in addition to the comparison with the previous research data, made it possible to identify two monoterpenoid indole alkaloids of the plumeran class. Compound $\mathbf{1}$ was identified as 15-methoxyaspidospermine. The presence of a methoxyl group at position C-11 in compound 2 allowed us to identify it as being $t$ 15-methoxypyrifolidine (Figure 2).

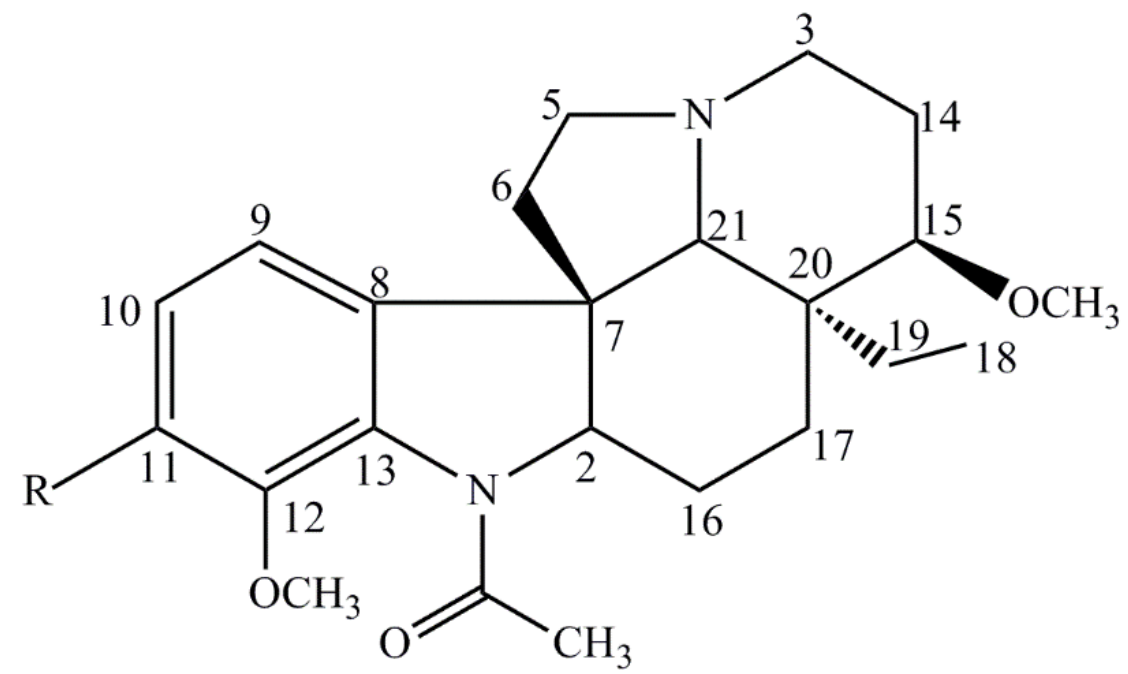

Figure 2. Compounds isolated from A. pyrifolium present in TAF-Ap. $1-\mathrm{R}=\mathrm{H}, \mathbf{2}-\mathrm{R}=\mathrm{OCH}_{3}$.

\subsection{Acute Toxicity}

The TAF-Ap dose of $200 \mathrm{mg} \mathrm{kg}^{-1}$ was $100 \%$ lethal to animals within $30 \mathrm{~min}$ of its administration and death was preceded by severe tremors. The $100 \mathrm{mg} \mathrm{kg}^{-1}$ dose caused death in a female one hour after administration; by the fourth hour, all the animals showed poor responses to tail pinching, low auricular reflex and impaired posture, as well as tremors and signs of sedation and forced breathing. Regarding the dose of $50 \mathrm{mg} \mathrm{kg}^{-1}$, no animal died; however, the animals presented signs of mild sedation and forced breathing in the first $24 \mathrm{~h}$. The lethal dose capable of killing $50 \%$ of animals $\left(\mathrm{LD}_{50}\right)$ was estimated to be $160 \mathrm{mg} \mathrm{kg}^{-1}$.

The mean values obtained for each group in the weight evolution of the animals showed significant differences for the dose of $100 \mathrm{mg} \mathrm{kg}^{-1}$; although they gained weight, the values for body mass increase in the animals of this group were lower than those of the negative control group and of the groups receiving the $50 \mathrm{mg} \mathrm{kg}^{-1}$ dose (Table 2). 
Table 2. Effect of oral administration of the total alkaloid fraction from A. pyrifolium (TAF-Ap) on weight evolution (change in body mass) by water and feed intake in 14 day-old male and female Swiss mice.

\begin{tabular}{|c|c|c|c|c|}
\hline Parameter & Sex & Saline Solution & TAF-Ap (50 mg kg $\left.{ }^{-1}\right)$ & TAF-Ap (100 $\left.\mathrm{mg} \mathrm{kg}^{-1}\right)$ \\
\hline Initial W. (g) & \multirow{3}{*}{$\mathbf{M}$} & $28.83 \pm 1.32$ & $27.67 \pm 2.58$ & $30.67 \pm 0.81$ \\
\hline Final W. (g) & & $33.17 \pm 1.31$ & $34.50 \pm 3.72$ & $31.50 \pm 3.72$ \\
\hline Gain (\%) & & 4.34 & 6.83 & $0.83^{* * *}$ \\
\hline Initial W. (g) & \multirow{3}{*}{$\mathbf{F}$} & $27.50 \pm 0.83$ & $25.00 \pm 1.41$ & $25.33 \pm 3.14$ \\
\hline Final W. (g) & & $32.00 \pm 1.26$ & $32.17 \pm 1.54$ & $26.31 \pm 3.18$ \\
\hline Gain $(\%)$ & & 4.50 & 7.17 & $0.98^{* * *}$ \\
\hline \multirow[t]{2}{*}{ Feed intake per day (g) } & $\mathbf{M}$ & $34.57 \pm 2.92$ & $37.29 \pm 3.42$ & $25.50 \pm 3.25^{* * *}$ \\
\hline & $\mathbf{F}$ & $36.71 \pm 2.94$ & $35.86 \pm 2.65$ & $23.07 \pm 2.30 * * *$ \\
\hline \multirow[t]{2}{*}{$\begin{array}{l}\text { Water consumption per } \\
\text { day }(\mathrm{mL})\end{array}$} & $\mathbf{M}$ & $52.14 \pm 4.25$ & $52.86 \pm 4.68$ & $56.43 \pm 2.25^{* * *}$ \\
\hline & F & $46.79 \pm 4.64$ & $50.00 \pm 3.39^{* * *}$ & $60.29 \pm 3.93^{* * *}$ \\
\hline
\end{tabular}

Initial W. = initial weight; Final W. = final weight; $\mathrm{M}=$ males; F = females. Results are expressed as mean \pm sd. $(n=5)$. Analysis of variance (ANOVA) followed by Tukey's post-test, ${ }^{* * *} p<0.001$. The absence of asterisks shows that the data were not significant.

Regarding the daily feed intake, those animals that received the $100 \mathrm{mg} \mathrm{kg}^{-1}$ dose consumed a smaller amount of food when compared to the negative control groups and those receiving the $50 \mathrm{mg} \mathrm{kg}^{-1}$ dose (Table 2). Still, as shown in Table 2, the groups that received the $100 \mathrm{mg} \mathrm{kg}^{-1}$ dose consumed a larger amount of water than the others. In addition, it was found that there was no significant difference when comparing the water and feed intake of animals receiving the $50 \mathrm{mg} \mathrm{kg}^{-1}$ dose in relation to the negative control.

Table 3 shows that there was a significant decrease in the relative weight of the livers of the animals receiving the $100 \mathrm{mg} \mathrm{kg}^{-1}$ dose compared to those receiving the $50 \mathrm{mg} \mathrm{kg}^{-1}$ dose and the negative control, which corroborates the results of the weight evolution shown in Table 2; these showed a lower weight gain in the animals that received the highest dose.

Table 3. Effect of oral administration of the total alkaloid fraction from A. pyrifolium (TAF-Ap) on relative organ weight of male and female Swiss mice at the end of the experiment.

\begin{tabular}{|c|c|c|c|c|}
\hline $\begin{array}{c}\text { Relative Weight of } \\
\text { Organs (g/100 g) }\end{array}$ & Sex & Negative Control & TAF-Ap (50 $\mathrm{mg} \mathrm{kg}^{-1}$ ) & TAF-Ap (100 mg kg $\left.{ }^{-1}\right)$ \\
\hline Liver & & $5.11 \pm 0.65$ & $5.06 \pm 0.55$ & $4.13 \pm 0.54 *$ \\
\hline Spleen & & $0.59 \pm 0.32$ & $0.73 \pm 0.47$ & $0.80 \pm 0.21$ \\
\hline Heart & $\mathbf{M}$ & $0.47 \pm 0.02$ & $0.50 \pm 0.05$ & $0.52 \pm 0.11$ \\
\hline Kidneys & & $1.23 \pm 0.64$ & $1.37 \pm 0.11$ & $1.24 \pm 0.16$ \\
\hline Liver & & $4.98 \pm 0.20$ & $4.95 \pm 0.47$ & $4.03 \pm 0.53 *$ \\
\hline Spleen & & $0.59 \pm 0.11$ & $0.45 \pm 0.11$ & $0.48 \pm 0.25$ \\
\hline Heart & $\mathbf{F}$ & $0.48 \pm 0.03$ & $0.45 \pm 0.04$ & $0.36 \pm 0.18$ \\
\hline Kidneys & & $1.08 \pm 0.11$ & $0.97 \pm 0.08$ & $0.85 \pm 0.44$ \\
\hline
\end{tabular}

$\mathrm{M}=$ males; $\mathrm{F}=$ females. Results are expressed as mean $\pm \mathrm{sd}$. $(n=5)$. One-way analysis of variance (ANOVA) followed by Tukey's post-test, ${ }^{*} p<0.05$. The absence of asterisks shows that the data were not significant.

In addition to body weight changes, the individual weight of each organ can also be considered as an indicator of drug-induced adverse effects, both of which are indicative of toxicity [14]. Regarding the macroscopic characteristics, no alteration in the color or shape of the organs was observed between the studied groups.

The acute toxicity test was useful to establish the doses employed in the anti-inflammatory and anti-nociceptive activity assays. The reason why doses above $50 \mathrm{mg} \mathrm{kg}^{-1}$ exerted harmful effects on the animals in the present study is that TAF-Ap is a concentrated fraction of alkaloids, enabling a greater chance of producing toxicity than crude extract.

For this same species, some experimental studies have already been carried out to prove toxicity. In an experimental study of goats at different gestational stages and fed with freshly harvested green leaves from A. pyrifolium $\left(4 \mathrm{~g} \mathrm{~kg}^{-1}\right.$ dose), during 19 days of consumption, miscarriage and embryonic losses were observed. Desiccated leaves were not able to cause reproductive changes, although the ingestion of the plant in the first 
34 days of gestation was shown to cause mortality [15]. In a survey of 60 respondents residing in the Western and Eastern Seridó of Rio Grande do Norte, including 17 producers and technicians, abortions or the births of weak animals were reported in 16 goats that ingested A. pyrifolium leaves during the drought period. Nine respondents also reported the occurrence of poisoning, which was characterized by hind limb stiffness and locomotion difficulty [16].

In a toxicity study of male and female Wistar rats with ethanolic extracts from A. pyrifolium, the females demonstrated reduced fetal weight and strong indications of maternal toxicity, in addition to motor disturbances and death at higher concentrations. The male rats were more resistant than the females. In the same study, it was found that A. pyrifolium extract promoted hemolysis and was lethal to the Artemia salina organism in an in vitro cytotoxicity test [17].

\subsection{Anti-Inflammatory Activity}

\subsubsection{Carrageenan-Induced Paw Edema}

In this model, an anti-edematogenic effect was observed in both the positive control group (indomethacin) and in the groups treated with TAF-Ap at doses of 20 and c. Here, the animals showed a reduction in the thickness of the paw that received the agent from the first hour until the fourth hour when compared to the negative control (Figure 3).

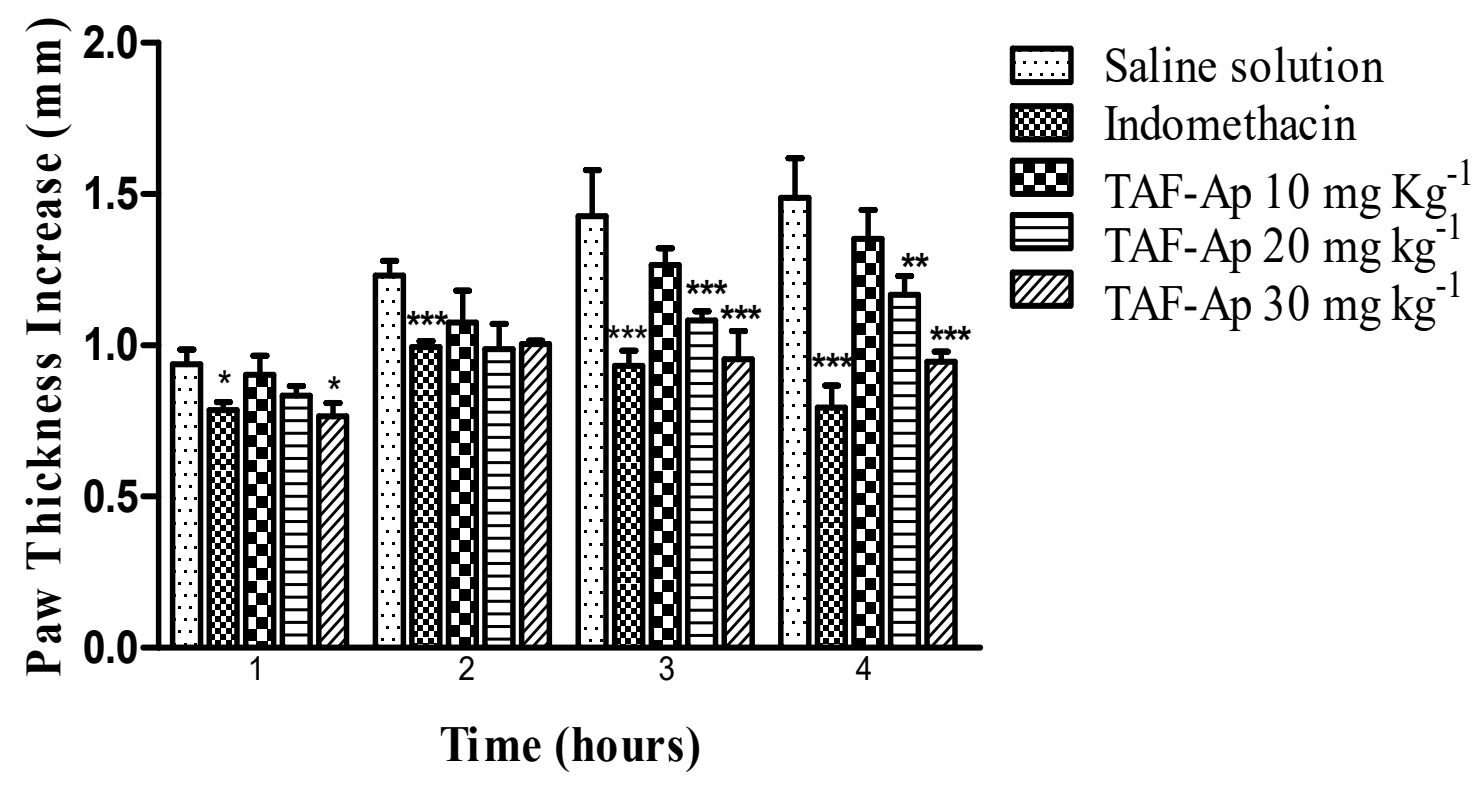

Figure 3. Evaluation of the anti-edematogenic effect of the total alkaloid fraction from A. pyrifolium (TAF-Ap) as a function of time after the induction of $1 \%$ carrageenan paw edema. Analysis of variance (ANOVA) followed by Tukey's post-test, ${ }^{*} p<0.05 ;{ }^{* *} p<0.01 ;{ }^{* * *} p<0.001$. The absence of asterisks shows that the data were not significant.

The $30 \mathrm{mg} \mathrm{kg}^{-1}$ dose of TAF-Ap presented a percentage of edema inhibition in the interval between the first and second hour (18.7\%) when compared to the group receiving indomethacin (19.5\%); after the second hour, the $20 \mathrm{mg} \mathrm{kg}^{-1}$ dose also presented a high inhibition percentage $(24.5 \%)$. The paws of the animals treated with the $30 \mathrm{mg} \mathrm{kg}^{-1}$ dose of TAF-Ap and indomethacin as a positive control were shown to present a lower weight at the end of the experiment when compared to the negative control, confirming the anti-edematogenic potential mentioned above (Figure 4). 


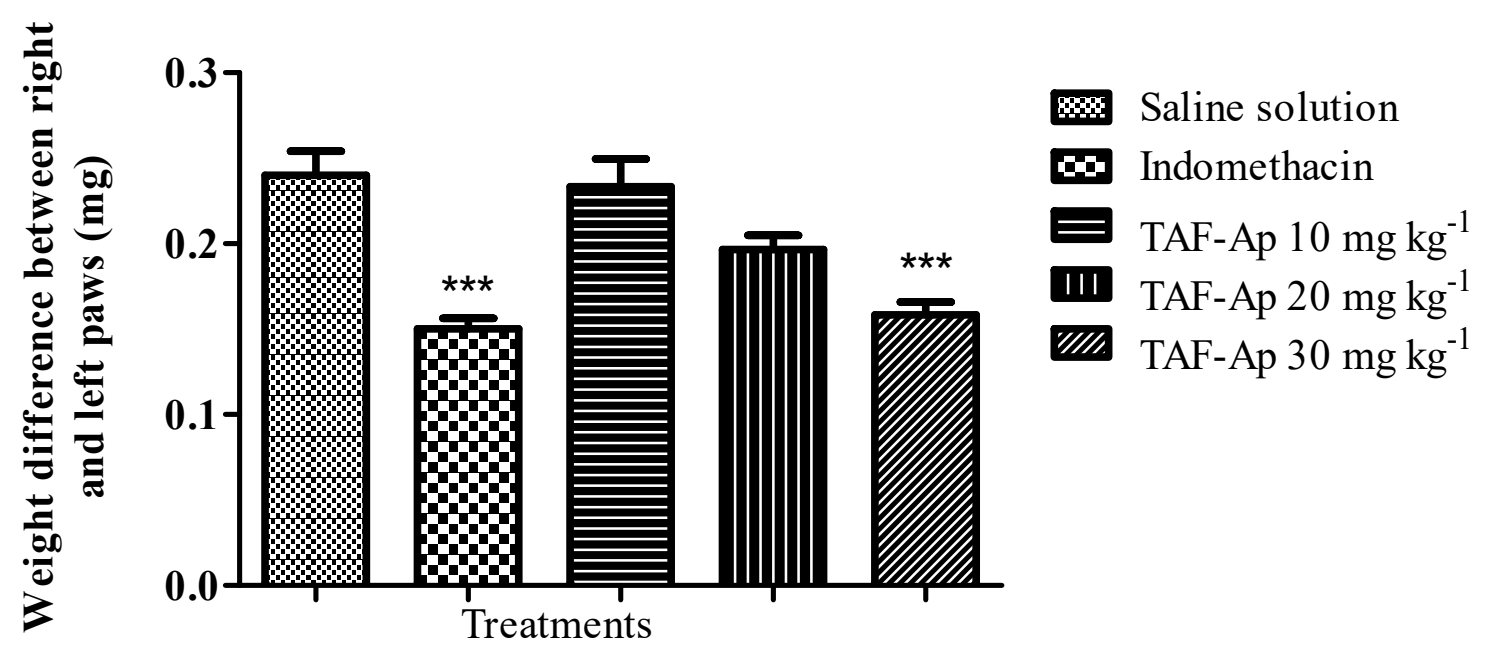

Figure 4. Comparison of paw weights that received 1\% carrageenan after the $4 \mathrm{~h}$ period that marked the end of the experiment. Analysis of variance (ANOVA) followed by Tukey's post-test $(* * * p<0.001)$. The absence of asterisks shows that the data were not significant.

After tissue injury, blood vessels in the injured area contract momentarily (vasoconstriction), followed by vasodilation and increased blood flow in the area, which can last from 15 min to several hours. The walls of these blood vessels, which normally only allow water and salts to pass through, become permeable, resulting in a rich fluid called exudate that eventually flows to the tissues. This is followed by white cell migration [18].

Paw edema testing is routinely performed to assess the degree of vascular permeability following tissue injury caused by carrageenan injection and promotes biphasic inflammation. This involves the initial phase, which occurs in the first hour after edema induction and features histamine release, 5-hydroxytryptamine, leukotrienes, kinins and cyclooxygenases; and the delayed phase, which runs from the first to the fourth hour, and is related to the production of prostaglandins, bradykinin and neutrophil infiltration [19]. Several published reports suggest that many cytokines, such as TNF- $\alpha$, IL-1 $\beta$, IL-2, IL-6 and PGE2, play a role during inflammation. Of these cytokines, TNF- $\alpha$ is the most important actor in inflammatory reactions, generating native protective responses, such as stimulating $\mathrm{T}$ cells and macrophages, as well as kinin and leukotriene release, and activating the production of additional inflammatory cytokines. Interleukin-6 (IL-6) is another important cytokine that is released by a variety of cells at the site of injury [18-20].

Thus, it is likely that the anti-inflammatory profile of TAF-Ap is related to the activation of this cascade, inhibiting the release of these mediators and, consequently, the vascular events of inflammation, which culminate in the dilation of small arterioles, the extravasation of proteins to the tissue and, consequently, edema formation [18].

\subsubsection{Carrageenan-Induced Peritonitis}

It was possible to observe a smaller amount of polymorphonuclear cells in the exudates collected in both the indomethacin group (41.0\% inhibition) and the $30 \mathrm{mg} \mathrm{kg}^{-1} \mathrm{TAF}-\mathrm{Ap}$ group (43.91\% inhibition), showing that there was a significant reduction in the recruitment of inflammatory cells (Figure 5). 


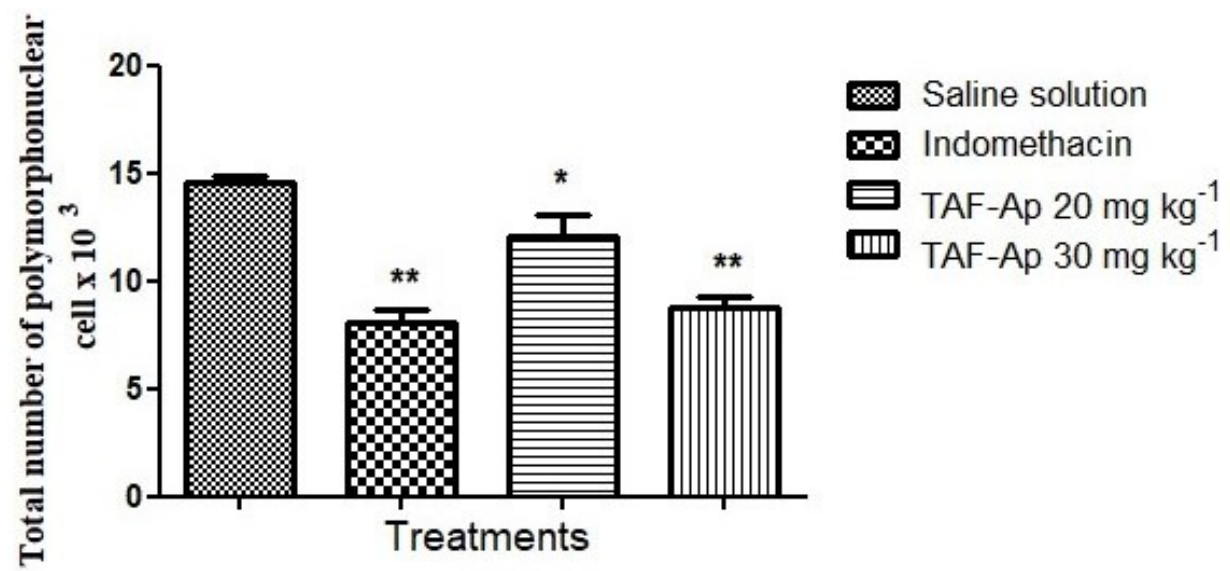

Figure 5. Comparison of the total number of polymorphonuclear cells observed in the intraperitoneal cavity of animals after $4 \mathrm{~h}$ of inflammation induction by $1 \%$ carrageenan solution. Analysis of variance (ANOVA) followed by Tukey's post-test * $p<0.05$, ${ }^{* *} p<0.01$.

An important sign in the inflammation process involves the recruitment of polymorphonuclear cells to the inflammatory foci. Upon stimulation, resident cells produce cytokines to communicate the threat to the injuring agent. These cytokines activate endothelial cells that express leukocyte adhesion molecules, mainly neutrophils; in turn, these produce reactive oxygen species, such as superoxide anion and nitric oxide, which are responsible for causing oxidative stress to eliminate the offending agent [21,22]. When the influx of neutrophils to the inflammatory site is exacerbated, it leads to tissue damage, and can result in serious injury to adjacent tissues when in constant circulation. Therefore, neutrophils play a key role in the pathogenesis of diseases such as atherosclerosis, obesity and rheumatoid arthritis [23,24].

Thus, we can suggest that the anti-inflammatory activity of TAF-Ap may also be related to the modulation of neutrophil migration, as well as the inhibition of the release of inflammatory mediators, as shown in the results observed in the paw edema test.

\subsection{Anti-Nociceptive Activity}

\subsubsection{1\% Acetic Acid-Induced Abdominal Writhing Test}

Acetic acid is responsible for the secretion of endogenous pain mediators, resulting in the increased synthesis of cyclooxygenases (COX), lipooxygenase (LOX) and prostaglandins, thus stimulating neurons responsible for nociception, which respond to anti-inflammatory drugs $[18,25]$. In addition, the action of acetic acid on macrophages and basophils in the abdominal cavity induces the release of cytokines such as IL- 8 , IL- $1 \beta$ and TNF- $\alpha$, and also triggers vasodilation and vascular permeability [25].

The doses tested showed the inhibition of abdominal writhing: TAF-Ap $10 \mathrm{mg} \mathrm{kg}^{-1}$ (75.42\%), TAF-Ap $20 \mathrm{mg} \mathrm{kg}^{-1}$ (76.67\%) and TAF-Ap $30 \mathrm{mg} \mathrm{kg}^{-1}$ (84.17\%) when compared to the negative control. These data allow us to state that TAF-Ap features analgesic properties (Figure 6). The potent reduction in abdominal contortions observed for TAF-Ap at the doses used may be justified by the inhibition of prostaglandin synthesis, acting on the nociceptive mechanisms of arachidonic acid metabolite processing or release through COX. 

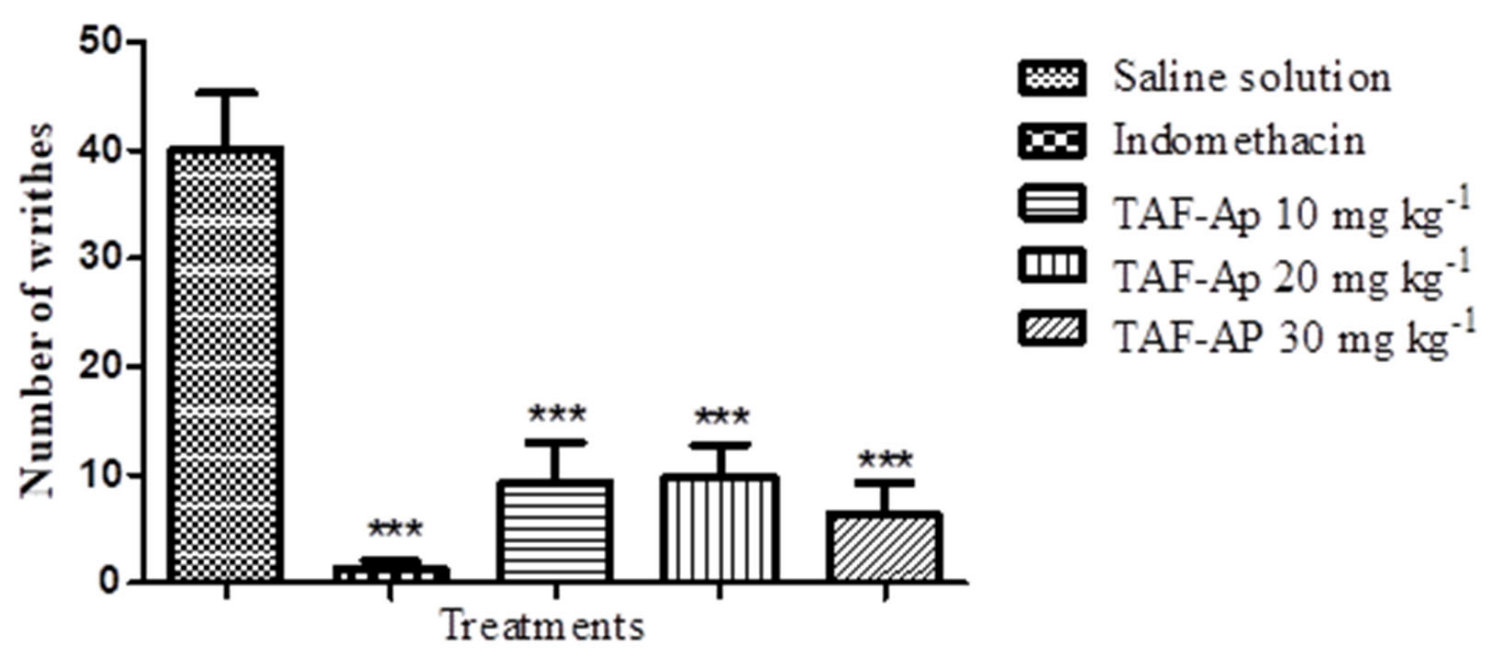

Figure 6. Evaluation of the effect of the total alkaloid fraction from A. pyrifolium (TAF-Ap) on the decrease in the number of abdominal writhing induced by the intraperitoneal injection of $1 \%$ acetic acid. Analysis of variance (ANOVA) followed by Tukey's post-test $(* * *<0.001)$.

\subsubsection{Formalin-Induced Nociception Test}

The injection of intraplantar formalin into the hind paw of an animal induces severe pain by the direct stimulation of nociceptors, characterized by vigorous licking, bites and bumps on the paw injected with the irritant. This test allows the verification of signals present in the modulation phase of nerve impulses, and also to observe the participation of endogenous systems, such as that of opioids $[25,26]$.

In this model, both the indomethacin group and the $30 \mathrm{mg} \mathrm{kg}^{-1} \mathrm{TAF}-\mathrm{Ap}$ group demonstrated a higher inhibition level than $50 \%$, with less time to stop licking at the end of phase I (neurogenic phase). In phase II (inflammatory phase), all doses of TAF-Ap significantly decreased the time spent licking, with the $30 \mathrm{mg} \mathrm{kg}^{-1}$ dose being the most effective (85.57\% inhibition) (Table 4$)$.

Table 4. Antinociceptive effect of the total alkaloid fraction from A. pyrifolium (TAF-Ap) in phases I (0-5 min) and II (15-30 $\mathrm{min}$ ) after $1 \%$ formalin-induced nociception.

\begin{tabular}{|c|c|c|c|c|}
\hline Treatments & $\begin{array}{c}\text { Time Animals Are } \\
\text { Licking Paw in Phase } \\
\text { I (0-5 min) }\end{array}$ & $\begin{array}{c}\text { Inhibition } \\
(\%)\end{array}$ & $\begin{array}{l}\text { Time Animals Remain } \\
\text { Licking Paw in Phase } \\
\text { II (15-30 min) }\end{array}$ & $\begin{array}{c}\text { Inhibition } \\
(\%)\end{array}$ \\
\hline Saline & $4.53 \pm 0.34$ & & $11.30 \pm 1.66$ & \\
\hline Indomethacin & $1.58 \pm 1.39 * *$ & $62.12^{* *}$ & $1.00 \pm 1.43^{* * *}$ & $91.15^{* * *}$ \\
\hline TAF-Ap $10 \mathrm{mg} \mathrm{kg}^{-1}$ & $3.14 \pm 1.09$ & 30.68 & $6.90 \pm 1.5$ & 38.93 \\
\hline TAF-Ap $20 \mathrm{mg} \mathrm{kg}^{-1}$ & $2.98 \pm 1.00$ & 34.21 & $3.4 \pm 2.0^{* *}$ & $69.91 * *$ \\
\hline TAF-Ap $30 \mathrm{mg} \mathrm{kg}^{-1}$ & $1.90 \pm 1.09 * *$ & $58.05^{* *}$ & $1.63 \pm 1.79 * * *$ & $85.57^{* * *}$ \\
\hline
\end{tabular}

Results are expressed as mean $\pm \mathrm{sd}$. $(n=6)$. Analysis of variance (ANOVA) followed by Tukey's post-test, ${ }^{* *} p<0.01 ;{ }^{* * *} p<0.001$. The absence of asterisks shows that the data was not significant.

The results related to the decrease in the number of phase II licks may contribute positively to the anti-inflammatory profile observed in the decrease of carrageenan paw edema, so that both the positive control and the TAF-Ap may have caused the inhibition of mediators responsible for increasing vascular permeability after $30 \mathrm{~min}$, reducing edema caused by the inflammatory agent. The results presented suggest that TAF-Ap exerts a central and peripheral effect against pain and inflammation, which corroborates data from another study [6], in which the $100 \mathrm{mg} \mathrm{kg}^{-1}$ dose of the aqueous extract of the seeds from A. pyrifolium also showed a decrease in late phase licking time similar to that of positive controls (morphine $5 \mathrm{mg} \mathrm{kg}^{-1}$ and indomethacin $10 \mathrm{mg} \mathrm{kg}^{-1}$ ). 
It can be inferred that by raising the pain threshold induced by intraperitoneal acetic acid injection and intra-implant formalin injection, and inhibiting the carrageenaninduced edematogenic effect and leukocyte migration, TAF-Ap is endowed with antinociceptive and anti-inflammatory activity, both of peripheral origin and associated with central mechanisms of pain and inflammation inhibition. These activities are related to the indolic alkaloids found in the extracts of the species of genus Aspidosperma, which could be confirmed from the isolation of the compounds 15-methoxyaspidospermine and 15-methoxypyrifolidine. This was the first pharmacological study conducted with the isolated fraction of alkaloids of the species A. pyrifolium.

\section{Materials and Methods}

\subsection{Vegetable Material Collection and Identification}

The stem barks from A. pyrifolium Mart. were collected at Capim Grande site, São José da Mata district, Campina Grande, Paraíba, in August 2014 (coordinates: S 7 ${ }^{\circ} 13^{\prime} 27.56^{\prime \prime}-\mathrm{W}$ $\left.36^{\circ} 00^{\prime} 53.37^{\prime \prime}\right)$. After collection, the material was identified by Prof. Dr. Leonardo Pessoa Felix and the exsiccata deposited in the Herbarium Jayme Coelho de Moraes at the Federal University of Paraíba, under the number 20104.

\subsection{Isolation and Characterization of Compounds}

The stem barks from A. pyrifolium Mart. were dried in an air circulation oven $\left(40^{\circ} \mathrm{C}\right)$ and powdered in a 10 mesh knife mill. The powder was exhaustively extracted with $96 \%(v / v)$ ethanol and rotary evaporated (Tecnal TE-21) to yield $552 \mathrm{~g}$ of crude ethanolic extract (CEE). Next, $112 \mathrm{~g}$ of CEE was subjected to a liquid-liquid partition, providing the following phases: hexane $(57.46 \% / 64.36 \mathrm{~g})$, chloroform $(18.03 \% / 20.2 \mathrm{~g})$, ethyl acetate $(1.25 \% / 1.4 \mathrm{~g})$ and methanol: $\mathrm{H} 2 \mathrm{O}-7: 3(v / v)(3.83 \% / 4.28 \mathrm{~g})$.

\subsection{Obtaining of the Total Alkaloids Fraction from A. pyrifolium (TAF-Ap)}

The CEE $(110 \mathrm{~g})$ was submitted for extraction of the total alkaloids fraction. The extract was initially treated with $2 \mathrm{~L}$ of $3 \%$ hydrochloric acid solution and subsequently filtered on filter paper. The residue was discarded and the filtrate was subjected to several extractions with chloroform. The acidic aqueous phase was basified with $\mathrm{NH}_{4} \mathrm{OH}$, stirred vigorously to $\mathrm{pH} 10$, and then extracted with chloroform [27]. Subsequently, the chloroform fraction was evaporated under reduced pressure in a rotary evaporator at $40^{\circ} \mathrm{C}$, yielding $2.06 \mathrm{~g}$ of the TAF-Ap.

\section{Isolation of Alkaloids from TAF-Ap}

The TAF-Ap (1.90 g) was subjected to medium pressure chromatography (BUCHI Pump Manager, model C-615, Flawil, Switzerland) using aluminum oxide 90 (70-270 mesh ASTM, MN) and binary mixtures of hexane and methanol in an increasing polarity gradient, providing 48 fractions. The chromatographic profile of sample $8(126 \mathrm{mg})$ was analyzed in an analytical HPLC (Infinity Series More Confident 1260 system, Agilent, Santa Clara, CA, United States). The fraction was diluted in $0.2 \%$ trifluoroacetic acid (TFA):acetonitrile (ACN) $(1: 1-v / v)$ aqueous solution at $1 \mathrm{mg} \mathrm{mL}^{-1}$ and the volume injected into the apparatus was $50 \mu \mathrm{L}$. A reverse phase $\mathrm{C}-18$ column was maintained at $40{ }^{\circ} \mathrm{C}$ and $0.2 \%$ TFA:ACN aqueous solution (77:23 to 65:35 v/v) was used as a mobile phase with a flow of $10 \mathrm{~mL} \mathrm{~min}^{-1}$, a time of $15 \mathrm{~min}$, and in gradient mode. After analysis in analytical HPLC, the sample was injected into semi-preparative HPLC (2767 Sample Manager System, Waters, with a UV-Vis photodiode detector, Milford, Massachusetts) using the same conditions as previously mentioned. At the end of the separation, a total of 10 fractions were obtained (Ap- 1 to Ap-10). Fraction Ap-3 was directed to structural analysis, which allowed the identification of compounds 1 and 2 (Figure 2). 


\subsection{Techniques Used for Structural Identification}

The mass spectra were obtained by injecting the samples into a high-performance liquid chromatograph with a diode array detector coupled with a low resolution electrospray ionization mass spectrometer (HPLC-DAD-ESI-MS; 2767 Sample Manager System, Waters, Milford, Massachusetts) and a quadrupolar analyzer ion trap (trap ions) operating in the positive mode. The ${ }^{1} \mathrm{H}$ and ${ }^{13} \mathrm{C}$ NMR spectra (500 and $125 \mathrm{MHz}$, acetone- $\mathrm{d}_{6}$ ) (1D and 2D) were recorded on a Varian Mercury spectrometer using TMS as the internal standard.

\subsection{Animals}

The study was carried out in strict accordance with the Standard Operating Procedures (Laboratory of Pharmacology at the State University of Paraiba, Campina Grande, Brazil) and approved by a veterinarian, who frequently monitored the health of the animals through physical condition assessments. All efforts were made to reduce the suffering of the experimental animals.

The animals were obtained from the Institute for Research in Pharmaceuticals and Medications (Iperfarm) of the Federal University of Paraíba (UFPB). Disease-free adult mice Swiss (Mus musculus) of both sexes, weighing between 25 and $30 \mathrm{~g}$, were used. The animals were housed in standard plastic cages in an environment with a controlled temperature and humidity, a light-dark cycle of $12 \mathrm{~h}$ and food and water ad libitum. All the mice underwent a period of at least 7 days of acclimatization prior to the procedure, being socialized through contact, including with humans. The animals were handled with care to minimize stress. The researchers confirm that the laboratory established a protocol for the use of humane endpoints in cases where animals became severely ill or moribund during the experiment, but none reported death or behavioral changes in animals. The animals received standard laboratory pellets and water ad libitum for both the adaptation period (7 days) and during the trial, except for the period of $12 \mathrm{~h}$ prior to the experiments, in which the access to food was restricted. Throughout the experiments, all of the animals received humane care according to the "Guide for the Care and Use of Laboratory Animals" prepared by the National Academy of Sciences [28]. At the end of the experiments, the animals were euthanized by intraperitoneal anesthetic overdose (ketamine $50 \mathrm{mg} \mathrm{kg}^{-1}$ and xylazine$3 \mathrm{mg} \mathrm{kg}^{-1}$ ), following the recommendation of resolution number 714 of 20 June 2002 of the Federal Council of Veterinary Medicine. The experimental protocols were submitted and approved by the Ethics Committee on Animal Use (CEUA) of the Faculty of Social and Applied Sciences of Campina Grande (FACISA) —Project Number/Protocol: 5402042015 and CIAEP/CONCEA: 01.001.2012.

\subsection{Chemicals and Reagents}

The following drugs and chemicals were used: indomethacin $10 \mathrm{mg}$ (Bayer, Leverkusen, Germany), dipyrone sodium $500 \mathrm{mg}$ (TEUTO, Goiás, Brazil), carrageenan (laboratory (BDH Chemicals ${ }^{\circledR}$, London, UK), formalin (BDH Chemicals ${ }^{\circledR}$, London, UK), (Merck, Kenilworth, NJ, USA), HPLC-grade acetonitrile (Merck, Germany, USA) and trifluoroacetic acid (Merck, Kenilworth, NJ, USA). TAF-Ap was dissolved in $0.9 \%$ saline solution. All the solutions were prepared immediately prior to the start of the experiments.

\subsection{Pharmacological Tests}

Acute Toxicity Assessment

The acute toxicity test was based on ANVISA Resolution No. 90/2004 and the Almeida Experimental Protocol [29], with some adaptations according to [30], where the behavioral alterations in the central and autonomic nervous system were evaluated along with the occurrence of death [31]. In this trial, a total of 48 adult mice $(n=5)$, corresponding to 8 groups, with 24 males and 24 females, were treated orally at doses of 50, 100 and $200 \mathrm{mg} \mathrm{kg}^{-1}$ of TAF-Ap; a control group received saline solution only. Parameters such as body mass, water and feed intake and excreta production were evaluated for $30 \mathrm{~min}, 1,2,4$, and every $24 \mathrm{~h}$ for 14 days. On day 15, the animals were weighed and euthanized. After euthanasia, 
weighing and macroscopic analysis of the viscera (liver, kidneys, spleen, lungs and heart) was carried out [32].

\subsection{Evaluation of Anti-Inflammatory Activity}

\subsubsection{Carrageenan-Induced Paw Edema}

The test was based on the methodology used by Zayed and Hassan (2014) [33]. Five groups of six animals each $(n=6)$ were treated orally with saline $(0.9 \%$; negative control), $10 \mathrm{mg} \mathrm{kg}^{-1}$ indomethacin (positive control) and TAF-Ap at doses of 10, 20 and $30 \mathrm{mg} \mathrm{kg}^{-1}$. After $30 \mathrm{~min}, 0.1 \mathrm{~mL}$ of $1 \%$ carrageenan solution was injected into the right hind paw subplantar region. Paw thickness was measured with a digital caliper before and up to the fourth hour after edematogenic stimulation. The anti-edematogenic effect was obtained by calculating the difference between the initial thickness of the paw that received the phlogistic agent and the thickness measured after each hour. The inhibition percentage was calculated using the following formula: Inhibition $=(\mathrm{V}-\mathrm{X}) / \mathrm{V} \times 100 \%$, where $\mathrm{V}$ is the measure of vehicle group edema and $X$ tests or positive control. To complement the results, the paw that received the phlogistic agent was cut with surgical scissors in the tibio-tarsal region for later comparison between weights, according to the methodology used by [34].

\subsubsection{Carrageenan-Induced Peritonitis}

Four groups of six animals each $(n=6)$ were treated orally with $10 \mathrm{mg} \mathrm{kg}^{-1}$ saline (negative control), $10 \mathrm{mg} \mathrm{kg}^{-1}$ indomethacin and TAF-Ap at doses of 20 and $30 \mathrm{mg} \mathrm{kg}^{-1}$. After $30 \mathrm{~min}$, a $1 \%$ carrageenan solution $(0.1 \mathrm{~mL} / 10 \mathrm{~g})$ was injected into the intraperitoneal cavity of the animals. Four hours after the induction of inflammation, the animals were sacrificed and the intraperitoneal cavity washed with $2 \mathrm{~mL}$ of alkaline phosphate buffer (pH 7.2). The solution containing the buffer plus the peritoneum cells was transferred to tubes containing $0.4 \mathrm{~mL}$ of Turk's solution. After five minutes, the global polymorphonuclear leukocyte count was performed in the Neubauer Chamber [35].

\subsection{Evaluation of Anti-Nociceptive Activity}

\subsubsection{Acetic Acid-Induced Abdominal Writhing Test}

Five groups of six animals each $(n=6)$ were treated orally with $10 \mathrm{mg} \mathrm{kg}^{-1}$ saline (negative control), dipyrone $500 \mathrm{mg} \mathrm{kg}^{-1}$ (positive control) and TAF-Ap at doses of 10, 20 and $30 \mathrm{mg} \mathrm{kg}^{-1}$. After $40 \mathrm{~min}$, a $1 \%$ acetic acid solution $\left(0.1 \mathrm{~mL} 10 \mathrm{~g}^{-1}\right)$ was injected into the intraperitoneal cavity and the animals were transferred to clear glass funnels and observed for $20 \mathrm{~min}$ to account for the number of abdominal contortions, followed by stretching of the lower limbs [36].

\subsubsection{Formalin-Induced Nociception}

Five groups with six animals each $(n=6)$ were treated orally with $10 \mathrm{mg} \mathrm{kg}^{-1}$ saline (negative control), $10 \mathrm{mg} \mathrm{kg}^{-1}$ indomethacin (positive control) and TAF-Ap at doses of G10, 20 and $30 \mathrm{mg} \mathrm{kg}^{-1}$. After $30 \mathrm{~min}, 20 \mu \mathrm{L}$ of $1 \%$ formalin was injected into the subplantar region of the right paw of the animals. The animals' reactivity was observed by recording the start and end time of licking the paw that received the phlogistic agent during the initial 5 min (Phase I-neurogenic) and between 15 and $30 \mathrm{~min}$ (Phase II-inflammatory). The calculation involved subtracting the final time by the initial time in each phase (Tf- To) [37].

\subsection{Statistical Analysis}

The results were evaluated using analysis of variance (ANOVA) followed by Tukey's post-test. All the results were expressed as mean \pm standard deviation (s.d.) with a minimum significance level of $p<0.05$ and analyzed using GraphPad Prism 5.0 software.

\section{Conclusions}

The results obtained in this research showed that Aspidosperma pyrifolium is an important plant species for the research of bioactive compounds. In this study, two monoterpenic 
indole alkaloids were isolated from the total alkaloid fraction. Through spectroscopic techniques, it was possible to identify 15-methoxyaspidospermine and 15-methoxypyrifolidine, compounds previously found in the species.

In the acute toxicity test, it was demonstrated that the TAF-Ap has considerable toxicity under the conditions evaluated and the $\mathrm{LD}_{50}$ was estimated at $160 \mathrm{mg} \mathrm{kg}^{-1}$. However, a potent anti-inflammatory effect was demonstrated in the paw edema and peritonitis tests induced by carrageenan, especially at the dose of $30 \mathrm{mg} \mathrm{kg}^{-1}(p<0.001)$ of TAF-Ap, promoted by the inhibition of the release of inflammation mediators and the modulation of neutrophil migration, respectively. In addition, TAF-Ap also showed interesting analgesic properties in the acetic acid-induced nociception test, in which there was an $84 \%$ decrease in the number of abdominal contortions at the dose of $30 \mathrm{mg} \mathrm{kg}^{-1}$, when compared to the negative control; and in the formalin test, with a significant decrease in the number of licks on the paw where the phlogistic agent was applied. Thus, the species whas shown to be a promising source of substances with pharmacological activity, with special attention paid to the toxicological potential presented. Therefore, its use should be conditioned to the determination of safe doses.

Supplementary Materials: The following are available online at https:/ /www.mdpi.com/article/ 10.3390/plants10112526/s1, Figure S1: UV spectrum of 1 and 2; Figure S2: ${ }^{1} \mathrm{H}$ NMR spectrum of 1 and $2\left(500 \mathrm{MHz}\right.$, acetone- $\left.\mathrm{d}_{6}\right)$; Figure S3: ${ }^{1} \mathrm{H}$ NMR spectrum expansion of 1 and $2(500 \mathrm{MHz}$, acetone- $\left.\mathrm{d}_{6}\right)$; Figure S4: ${ }^{1} \mathrm{H}$ NMR spectrum expansion of 1 and $2\left(500 \mathrm{MHz}\right.$, acetone- $\left.\mathrm{d}_{6}\right)$; Figure S5: ${ }^{1} \mathrm{H}$ NMR spectrum expansion of 1 and $2\left(500 \mathrm{MHz}\right.$, acetone- $\left.\mathrm{d}_{6}\right)$; Figure S6: ${ }^{13} \mathrm{C}$ NMR spectrum of 1 and $2\left(125 \mathrm{MHz}\right.$, acetone- $\left.\mathrm{d}_{6}\right)$; Figure S7: ${ }^{13} \mathrm{C}$ NMR spectrum expansion of 1 and $2(125 \mathrm{MHz}$, acetone$\mathrm{d}_{6}$ ); Figure S8: heteronuclear correlation map-HSQC 1 and 2 (acetone- $\mathrm{d}_{6}$; Figure S9: heteronuclear correlation map-HSQC expansion of 1 and 2 (acetone- $\mathrm{d}_{6}$ ); Figure S10: heteronuclear correlation map-HMBC of 1 and 2 (acetone- $\mathrm{d}_{6}$ ); Figure S11: heteronuclear correlation map-HMBC expansion of 1 and 2 (acetone- $\mathrm{d}_{6}$ ); Figure S12: heteronuclear correlation map-HMBC expansion of 1 and 2 (acetone- $\mathrm{d}_{6}$ ); Figure S13: NOESY spectrum expansion of 1 and 2 (acetone- $\mathrm{d}_{6}$ ).

Author Contributions: H.d.S.A. worked on the structural elucidation and participated in manuscript and project writing. F.S.V.L. prepared the extracts, isolated the compounds, performed the pharmacological activities and participated in manuscript writing. V.F.d.S. helped in the compounds purification. J.F.T. participated on the structural elucidation. V.L.d.S. supervised the pharmacological activities and manuscript correction. All authors have read and agreed to the published version of the manuscript.

Funding: This study was financed by the State University of Paraiba grant 001/2021 and CAPES/Ministry of Education-Brazil.

Institutional Review Board Statement: All experiments were carried out in accordance with the standards established by the Brazilian Society of Science in Laboratory Animal (SBCAL) and with the standards established by the National Institute of Health Guide for Care and Use of Laboratory Animals. This study was approved by the Ethics Committee on Animal Use (CEUA) of the Faculty of Social and Applied Sciences of Campina Grande (FACISA) —Project Number/Protocol: 5402042015 and CIAEP/CONCEA: 01.001.2012.

Informed Consent Statement: Not applicable.

Data Availability Statement: Data available on request.

Acknowledgments: We wish to thank IPeFarm/Federal University of Paraíba and INSA/National Institute of Semiarid for their support of our analyses.

Conflicts of Interest: The authors declare no conflict of interest. 


\section{References}

1. Sostres, C.; Gargallo, C.J.; Arroyo, M.T.; Lanas, A. Adverse effects of non-steroidal anti- inflammatory drugs (NSAIDs, aspirin and coxibs) on upper gastrointestinal tract. J. Best Pract. Res. Clin. Gastroenterol. 2010, 24, 121-132. [CrossRef]

2. Chiu, Y.J.; Huang, T.H.; Chiu, C.S.; Lu, T.C.; Chen, Y.W.; Peng, W.H.; Chen, C.Y. Analgesic and Antiinflammatory Activities of the Aqueous Extract from Plectranthus amboinicus (Lour.) Spreng. Both in vitro and in vivo. Evid. Based Complementary Altern. Med. 2011, 2012, 508137.

3. Nunes, D.S.; Koike, L.; Taveira, J.J.; Reis, F.A.M. Indole alkaloids from Aspidosperma pruinosum. Phytochemistry 1992, 31, $2507-2511$.

4. Tigre, C.B. Forestry for Xerophilous Forests; DNOCS: Petrolina, Brazil, 1968; p. 175.

5. Bourdy, G.; Oporto, P.; Gimenez, A.; Deharo, E. A search for natural bioactive compounds in Bolivia through a multidisciplinary approach. Part VI. Evaluation of the antimalarial activity of plants used by Isoceño-Guaraní Indians. J. Ethnopharm. 2004, 93, 269-277. [CrossRef] [PubMed]

6. Nogueira, P.C.N.; Araújo, R.M.; Viana, G.S.B.; Araújo, D.P.; Braz-Filho, R.; Silveira, E.R. Plumeran Alkaloids and Glycosides from the Seeds of Aspidosperma pyrifolium Mart. J. Braz. Chem. Soc. 2014, 25, 2108-2120.

7. Araújo, D.P.; Nogueira, P.C.N.; Santos, A.D.C.; Costa, R.O.; Lucena, J.D.; Gadelha-Filho, C.V.J.; Lima, F.A.V.; Neves, K.R.T.; Leala, L.K.A.M.; Silveira, E.R.; et al. Aspidosperma pyrifolium Mart: Neuroprotective, antioxidant and anti-inflammatory effects in a Parkinson's disease model in rats. J. Pharm. Pharmacol. 2018, 70, 787-796. [CrossRef]

8. Mitaine-Offer, A.C.; Sauvain, M.; Valentin, A.; Callapa, J.; Maille, M.; Zeches-Hanrot, M. Antiplasmodial activity of Aspidosperma indole alkaloids. Phytomedicine 2002, 9, 142-145. [CrossRef]

9. Guimarães, H.A.; Braz-Filho, R.; Vieira, I.J.C. ${ }^{1} \mathrm{H}$ and ${ }^{13} \mathrm{C}-\mathrm{NMR}$ Data of the Simplest Plumeran Indole Alkaloids Isolated from Aspidosperma Species. Molecules 2012, 17, 3025-3043. [CrossRef]

10. Pereira, M.M.; Jácome, R.L.R.P.; Alcântara, A.F.C.; Alves, R.B.; Raslan, D.S. Indole alkaloids from species of the Aspidosperma (Apocynaceae). Quim. Nova 2007, 30, 970-983. [CrossRef]

11. Marques, M.F.S.; Kato, L.; Filho, H.F.L.; Reis, F.A.M. Indole alkaloids from Aspidosperma ramiflorum. Phytochemistry 1996, 41, 963-967. [CrossRef]

12. Verpoorte, R. Methods for the Structure Elucidation of Alkaloids. J. Nat. Prod. 1986, 49, 1-25. [CrossRef]

13. Gilbert, B.; Ferreira, J.M.; Owellen, R.J.; Swanholm, C.E.; Budzikiewicz, H.; Durham, L.J.; Djerassi, C. Mass spectrometry in structural and stereochemical problems pyrifoline and refractidine. Tetrahedron Lett. 1962, 3, 59-67. [CrossRef]

14. Raza, M.M.; Al-Shabanah, O.A.; El-Hadiya, H.T.M.; Al-Majed, A.A. Effect of prolonged vigabatrin treatment of hematological and biochemical parameters in plasm, liver and kidney of Swiss albino mice. Sci. Pharm. 2002, 70, 135-145. [CrossRef]

15. Medeiros, R.M.T.; Neto, S.A.G.; Riet-Correa, F.; Schild, A.L.; Sousa, N.L. Embryonic mortality and abortion in goats caused by Aspidosperma pyrifolium. Braz. J. Vet. Res. 2004, 24, 42-43.

16. Silva, D.M.; Riet-Correa, F.; Medeiros, R.M.T.; Oliveira, O.F. Toxic plants for ruminants and horses in the western and eastern Seridó of Rio Grande do Norte. Braz. J. Vet. Res. 2006, 26, 223-236.

17. Lima, M.C.J.S.; Soto-Blanco, B. Poisoning in goats by Aspidosperma pyrifolium Mart.: Biological and cytotoxic effects. Toxicon 2010, 55, 320-324. [CrossRef]

18. Gupta, A.K.; Parasar, D.; Sagar, A.; Choudhary, V.; Chopra, B.S.; Garg, R.; Khatri, N. Analgesic and Anti-Inflammatory Properties of Gelsolin in Acetic Acid Induced Writhing, Tail Immersion and Carrageenan Induced Paw Edema in Mice. PLoS ONE 2015, 10 , e0135558. [CrossRef] [PubMed]

19. Chen, H.; Pu, J.; Liu, D.; Yu, W.; Shao, Y.; Yang, G.; Xiang, Z.; He, N. Anti-Inflammatory and Antinociceptive Properties of Flavonoids from the Fruits of Black Mulberry (Morus nigra L.). PLoS ONE 2016, 5, e0153080. [CrossRef]

20. Lee, S.O.; Jeong, Y.J.; Yu, M.H.; Lee, J.W.; Hwangbo, M.H.; Kim, C.H.; Lee, I.S. Wogonin suppresses TNF- $\alpha$ - induced MMP-9 expression by blocking the NF- $\mathrm{kB}$ activation via MAPK signaling pathways in human aortic smooth muscle cells. Biochem. Biophys. Res. Commun. 2006, 351, 118-125. [CrossRef]

21. Chi, Y.S.; Lim, H.; Park, H.; Kim, H.P. Effects of wogonin, a plant flavone from Scutellaria radix, on skin inflammation: In vivo regulation of inflammation associated gene expression. Biochem. Pharmacol. 2003, 66, 1271-1278. [CrossRef]

22. Mizokami, S.S.; Hohmann, M.S.N.; Staurengo-Ferrari, L.; Carvalho, T.T.; Zarpelon, A.C.; Possebon, M.I.; de Souza, A.R.; Veneziani, R.C.S.; Arakawa, N.S.; Casagrande, R.; et al. Pimaradienoic Acid Inhibits Carrageenan Induced Inflammatory Leukocyte Recruitment and Edema in Mice: Inhibition of Oxidative Stress, Nitric Oxide and Cytokine Production. PLoS ONE 2016, 11, e0149656. [CrossRef]

23. Medzhitov, R. Origin and physiological roles of inflammation. Nature 2008, 454, 428-435. [CrossRef] [PubMed]

24. Németh, T.; Mócsai, A. The role of neutrophils in autoimmune diseases. Immunol Lett. 2012, 143, 9-19. [CrossRef]

25. Radu, B.M.; Bramanti, P.; Osculati, F.; Flonta, M.L. Neurovascular unit in chronic pain. Mediat. Inflamm. 2013, 64, 1-18. [CrossRef] [PubMed]

26. Parveen, Z.; Deng, Y.; Saeed, M.; Dai, R.; Ahamad, W.; Yu, Y.H. Antiinflammatory and analgesic activities of Thesium chinense Turcz extracts and its major flavonoids, kaempferol and kaempferol-3-Oglucoside. Yakugaku Zasshi 2007, 127, 1275-1279. [CrossRef] [PubMed]

27. Santos, G.L.D.; Lemos, E.L.; Fernandes, A.F.C.; Rocha, W.R.V.; Catão, R.M.R.; Braz-Filho, R.; Tavares, J.F.; Fechine, I.M.; Alves, H.S. Phytochemical study of Harrisia adscendens. Braz. J. Pharm. 2018, 28, 298-302. [CrossRef] 
28. Garber, J.; Barbee, R.; Bielitzki, J.; Clayton, L.; Donovan, J. Guide for the Care and Use of Laboratory Animals, 8th ed.; The National Academy Press: Washington, DC, USA, 2010.

29. Zimmenann, M. Ethical guidelines for investigations of experimental pain in conscious animals. Pain 1983, 16, 109-110. [CrossRef]

30. Lorke, D. A new approach to practical acute toxicity testing. Arch. Toxicol. 1983, 54, 275-287. [CrossRef] [PubMed]

31. Escobedo-Martínez, C.; Guzman-Gutiérrez, S.L.; Hernandez-Mendez, M.M.; Cassini, J.; Trujillo-Valdivia, A.; Orozoco-Castellanos, L.M.; Enríquez, R.G. Heliopsis longipes: Anti-arthritic activity evaluated in a Freund's adjuvant-induced model in rodents. Braz. J. Pharmac. 2017, 27, 214-219. [CrossRef]

32. Castro, K.N.C.; Carvalho, A.L.O.; Almeida, A.P.; Oliveira, D.B.; Borba, H.R.; Costa, S.S.; Zingali, R.B. Preliminary in vitro studies on the Marsipianthes chamaedrys (bóia-caá) extracts at fibrino clotting induced by snake venoms. Toxicon 2003, 41, 929-932. [CrossRef]

33. Zayed, M.; Hassan, M. Synthesis and biological evaluation studies of novel quinazolinone derivatives as antibacterial and anti-inflammatory agents. Saudi Pharm. J. 2014, 22, 157-162. [CrossRef] [PubMed]

34. Cunha, F.Q.; Souza, G.E.; Souza, C.A.; Cerqueira, B.C.; Ferreira, S.H. In-vivo blockage of neutrophil migration by LPS is mimicked by a factor released from LPS-stimulated macrophages. Br. J. Exp. Pathol. 1989, 70, 1. [PubMed]

35. Ferrándiz, M.L.; Alcaraz, M.J. Anti-inflammatory activity and inhibition of arachidonic acid metabolism by flavonoids. Agents Actions 1991, 32, 283-288. [CrossRef] [PubMed]

36. Koster, R.; Anderson, M. Acetic acid for analgesic screening. Fed. Proc. 1959, 18, 412.

37. Hunskaar, S.; Hole, K. The formalin test in mice: Dissociation between inflammatory a non-inflammatory pain. Pain 1987, 30, 103-114. [CrossRef] 